\title{
OS DENTES DO POEMA
}

Roberto Rals

Benedito Nunes, em magistral estudo sobre João Cabral de Melo Neto, refere-se aos três exílios do poeta: o primeiro quando, menino, abandonou o vale do Capibaribe; o segundo, ao deixar 0 Recife para viver no Rio de Janeiro; e o último, iniciado em 1947, saindo do pais para assumir postos diplomáticos no exterior. O professor paraense, depois de lembrar Carlos Drumond de Andrade "poeta este de um só e profundo exílio, desterrado de Itabira" -, acrescenta, voltando a Cabral:

como movimento de separação e retorno, de ida e volta, permitindo a percepção distanciada de uma realidade outrora próxima, que se torna, por contraste com aquela em que se passou a viver, tanto mais nítida quanto mais lonqínqua e cristalizada, a dialética do desferramento, atuante na poesia brasileira, de Gonçalves Dias a Oswald de Andrade, de Sousândrade a Carlos Drummond, atingiu a obra de Cabral, daí por diante quase toda elaborada no estrangeiro'.

Se bem entendemos o ensaísta, o fato de se encontrar afastado do país, num "exílio profissional", terá levado o poeta pernambucano a tematizar a paisagem nordestina, em sua literatura. Sintomaticamente, o primeiro texto que, de forma evidente, problematiza a região de onde se exilou Cabral, dando início ao "período de construção" de sua poesia (Benedito Nunes), é "O cão sem plumas", de 1949-1950 - sendo o livro que o antecede, a "Psicologia da composição" com a "Fábula de Anfion e Antíode", de 46-47, "o tríptico da poética negativa de João Cabral" (Benedito Nunes). A visão dis-

1 NUNES, Benedito. João Cabral de Melo Neto. 2. ed. Petrópolis, Vozes, 1974. p. 15.

2 Como afirmava o ensaísta de $O$ dorso do tigre, em passagem há pouco transcrita, vários poetas brasileiros escreveram sobre o exilio, como Gonçalves Dias, Casimiro de Abreu, Oswald de Andrade, Murilo Mendes, Carlos Drummond de Andrade. Mário Quintana, todos compilados na antologia organizada por Dirce Cortes RIEDEL et alii. Literatura brasileira em carso. 4. ed. Rio de Janeiro, Bloch, 1971. p. 373-8. A questão do exilio - a sensação de sermos desterrados em nossa própria terra atravessa nossa cultura, vinca nossa personalidade e ecoa na Literatura Brasileira como um topoi, que a percorre inteira. Joāo Cabral, a seu modo, se insere nesta linhagem. 
tanciada favoreceu o poeta no sentido de melhor compreender o horrem nordestino e seu espaço, permitináo que as captasse de maneira mais aguda.

Claro está, porém, que esta recuperação do cenário pernambucano por João Cabral se dá na linguagem, se faz poeticamente. E nessa medida que poderíamos falar num exílio no verbo². Ocorre que, ao apreender no poema uma realidade regional, a poesia cabralina nos revela de modo contundente, cortante, esta mesma realidade - o poema tem dentes.

E nosso propósito, neste trabalho, incursionar por dois poemas longos do "tríptico do Capibaribe"3 - "O cão sem plumas" e "Morte e vida severina"4.

\section{O QUE VIVE FERE}

"O cão sem plumas" está dividido em quatro partes, tituladas: I - Paisagem do Capibaribe, II - Paisagem do Capibaribe, III Fábula do Capibaribe, IV - Discurso do Capibaribe.

O exame destes títulos nos autoriza desde logo a fazer algumas consideraçరes. O eixo central desta composição é, evidentemente, o rio (Capibaribe), assim como o será de "O rio" e do "Auto de Natal pernambucano", os outros dois componentes do citado tríptico.

As duas primeiras partes, a julgar por seus títulos, devem ser descritivas, focalizando a paisagem. Não são raros os poemas descritivos em Cabral, bastando evocar textos como "Litoral de Pernambuco", "O mar e o canavial", ou seu revés, "O canavial e o mar" - configurando o que Benedito Nunes batiza de "geografia poética" cabralina ${ }^{5}$.

Ao lermos o título da terceira parte, pensamos de imediato num paralelo com as fábulas de La Fontaine - obras parabólicas, que falam de animais, mas cuị, moral se aplica aos seres humanos. Aventamos a hipótese de que esta parte do poema também seria ilustrativa, parabólica, e dela se extrairia um ensinamento, correspondendo então esta moral à última parte, o discurso do Capibaribe.

3 Quem usa a expressão é Sebastião Uehoa LEITE. Participaçäo da palavra poética. Petrópolis, Vozes, 1966. Mas BARBOSA, João Alexandre. A imitaçāo da forma; uma leitura de Joăo Cabral de Melo Neto. São Paulo, Duas Cidades, 1975. p. 91, a atribui aos críticos espanhois Crespo e Bedate.

4 In: MElo NeTO, Joāo Cabral. Poesias completas. Rio de Janeiro, Sabiá, 1968. Citaremos por essa edição, indicando as páginas no corpo do trabalho.

5 NUNES, p. 16. 
Ora, a crítica já detectou "o sentido didático da poesia de João Cabral"6.

Sobre o rio versa a primeira parte. Trata-se de uma paisagem geográfica. O poema, podemos adiantar, vai desenvolver, como em "Morte e vida severina", a metáfora do título. Ela, é desdobrada no princípio da 3. " estrofe: "Aquele rio era como um cão sem plumas" (p. 305). O rio será sempre caracterizado de forma negativa, ou seja: pelo que não é, pelo que não tem, pelo que lhe falta - não sabe da água, mas apenas do lodo e da lama; não se abre aos peixes; cresce grávido de terra negra; marca-o a estagnação.

Aqui impõe se um parênteses. Sabemos que a significação de úm texto literário resulta de um diálogo, de uma interação leitortexto. Texto e leitor trazem propostas de sentido. A leitura as sintoniza, daí surgindo a interpretação daquele texto por um dado leitor ${ }^{7}$. Aceita esta descrição sumária, é fácil inferir que o leitor tem uma expectativa ao ler um texto qualquer. A leitura aciona, seu repertório - um complexo elenco de vivências, conhecimentos (inclusive da Literatura). Nele incluiríamos significações que o senso conıum empresta às palavras.

Assim é que, em geral, ao depararmos com a palavra 'rio', tendemos a imaginar um rio de águas limpas, abundante de peixes, pois nos habituamos a tal imagem de rio. O Capibaribe do poema, entretanto, em nada, se assemelha à idéia que o senso comum associaria à palavra 'rio'. Observe-se que sua caracterização se faz, conforme dizíamos, negando a noção ordinária de rio.

Tal processo de desmistificação 8 de imagens do senso comum

6 NUNES, p. 166.

7 Sobre a problemática da leiutra, consultar Roberto REIS. Por uma teoria da leitura. Revista de Cultura Vozes, 71(10): 135-40, 1977; A leitura como diálogo. Correio do Povo. Caderno de Sábado, Porto Alere, p. 16, 19 ago. 1978; Ler/dialogar, notas para uma teoria da leitura. Minas Gerais. Suplemento Literário, Belo Horizonte, 13(634) : 4-5, 18 nov. 1978; O lugar da crítica e a crítica do lugar. Minas Gerais. Suplemento Literário, Belo Horizonte, 14(681): 6-7, 20 out. 1979. Ver também Jonathan CULLER. Strncturnlist poetics. Ithaca, Cornell University Press, 1975. A estética da recepçāo alemā tem desenvolvido a questāo. Ver Wolfgang ISER. The net of reading. Baltimore, Johns Hopkins University Press, 1978. Para uma visão panorâmica da estética da recepção, em língua portuguesa, ver LIMA, Luiz Costa, org. A literatura e leitor. Rio de Janeiro, Paz e Terra, 1979.

8 Esta desmistificação corresponderia ainda ao rechaçar de uma visão fantasiosa, "sonhada" do rio e do homem do Capibaribe. O rio, por exemplo, nada sabe da "fonte cor de rosa". Nesta altura de sua produção, CABRAL nega o sonho. Leiamos: "como é muito mais espesso (e o real é espesso) / o sangue de um homem / do que o sonho de um homem" (p. 317). A poesia cabralina é anti-sentimental, anti-emotiva, anti-fantasiosa. Daf ser uma antilira. 
nos parece claro nos versos "abre-se em flores / pobres e negras / como negros. / Abre-se numa flora / suja e mais mendiga / como são os mendigos negros" (p. 306). O senso comum jamais pensaria a palavra 'flor' vinculada a algo que não fosse agradável, positivo: perfume, pétalas, beleza, cor. Mas a flor/flora do poema, do Capitaribe do poema, é negra e suja.

Com este procedimento estilistico, o texto vai gradativamente abalando noções do senso comum, rechaçando significações cristalizadas das palavras, num desmascaramento que constrói no leitor, através do poema, outra imagem de rio, de flor. Este trabalho inicia-se no nível mínimo do sintagma, e produzirá ao final uma nova visão do Capibaribe, ensinando o leitor.

Munidos dessa visão lama do rio enveredamos pela segunda parte. A paisagem agora é humana. O poema se ocupa do homem que vive às margens do Capibaribe. Refaz-se a metbfora-base, pora nela se insertar o ser humano: "como o rio / aqueles homens / são como cães sem pluma" (p. 309). Como o Capibaribe, o homem também é pintado por negação: são homens sem pluma, secos mais além; perdem-se na água do rio, em lama; o rio sabe daqueles homens; impossivel dizer onde naquele homem começa o homem; homem que está mais aquém do homem, que não rói, não grita não sangra, do mesmo modo que o rio crescia sem explodir. Homem sem dente $\left(9 .^{\circ}\right.$ e $10^{\circ}$ estrofes da Parte II, pp. 310-11). Rio, lama, terra $\epsilon$ homem se confundem (12. estrofe - p. 311$)$.

Podemos escrever:

1) Se: RIO = CAO SEM PLUMAS;

2) e: HOMEM = CAO SEM PLUMAS;

3) logo: RIO $=$ HOMEM = CAO SEM PLUMAS.

Compreendemos agora que as duas primeiras partes, embora falem sobre duas paisagens "distintas" - uma física, tematizando o rio Capibaribe; outra humana, tematizando o homem do Capibaribe -. podem receber o mesmo título, pois este rio e este homem são iguais, ambos marcados pela lama.

De igual modo, notamos que tanto o rio quanto o homem são caracterizados, basicamente, pelo que thes falta. $O$ poema desmistifica também uma determinada idéia de homem. O homem ribeirinho do Capibaribe é o contrário do homem. Escrevamos, então:

1) $\mathrm{RIO}=0$ que the falta;

2) $H O M E M=o$ que the falta; 
3) Se: RIO = HOMEM = CAOO SEM PLUMAS;

4) logo: CAOO SEM PLUMAS = o que falta. é não-ser:

Com efeito, lemos em Benedito Nunes que ser cão sem plumas

todo ser violentado, cujos atributos se truncam e se confundem (...) é um cão sem plumas. Exposto a uma geral corrosão ele é natureza desfalcada. Sua forma do existir é não-ser, pois que só existe como realidade negada em si mesma. $O$ que a nega e desrealiza, até fundi-la com - rio, é uma potência, anônima, que tem a força opaca, viscosa, pobremente fecunda e estagnada das águas do Capibaribe. O rio conhece os homens sem pluma, seus homônimos, que vão nele perder-se numa conivência de suas naturezas idênticas, ambas corroídas ou desfalcadas, ambas se confundindo na dissolução comum, que humaniza o rio e fluvializa o homem. Mal podem ser distinguidas, no estado de privação da natureza desplumada de que partilham, a paisagem física da paisagem humana'.

A caracterização por negação obedece a um duplo movimento. Inicia colocando o que rio e homem não são - vale dizer, não correspondem a uma idéia pré-concebida (senso comum) de rio, ou de homem (o procedimento é mais nítido no tocante ao primeiro termo). Em seguida, o texto mostra o que rio e homem são - e este ser é não-ser, é ser "cão sem plumas" (agora, percebe-se isto com maior clareza a propósito do segundo termo). Deste modo, o poema leva a!ém das últimas conseqüências, ao "máximo menos", o desfalque humano do homem do Capibaribe. Se poderíamos afirmar que o senso comum relaciona à palavra 'homem', para simplificar, uma total "felicidade" - alimentação, conforto, trabalho, etc. - o "Cão sem plumas" sequer parte daí (o "máximo mais" de homem), sendo esta imagem, por assim dizer implícita, negada. O homem-lama não tem camisa, passa fome, é seco mais além, nele se rompeu "o fio de homem", não se sabe "onde começa o homem naquele homem" (p. 311).

Ser desplumado, por conseguinte, é não-ser ${ }^{10}$ é ser carente, é ser negado, corroído, desfalcado. Constatamos assim que a nega-

9 NUNES, p. fig.

10 "Cäo sem plumas", em consonância com a observạ̧āo da nota 8, se vincularia também n essn visāo descarnada, não fnntasiosn, "Mesplumada" do rio. "A condiçño do cāo/rio". escreve Joño Alexandre BARBOSA, "näo permite $[\ldots]$ a lincuagem de adorno". (p. 93). 
ção em Cabral, ademais de ser um processo poético, de figurar aqui (como sucederá também em "Morte e vida severina") na construção do poema, tem um valor ético, moral e social11.

Caracterizados rio e homem pelo que lhes é negado, o poema inverterá seu trajeto. Na terceira parte, fábula do Capibaribe, entra em cena o mar, que resiste ao rio, que a ele se fecha. O mar é ácido, destrói o rio. $O$ mar é roedor, tem dentes $\left(4 .^{\circ}\right.$ e $5 .^{\circ}$ estrofes desta parte, p. 313), ao contrário do homem. Rio e mar se opõem: o rio é sujo, negro, território da, lama; o mar é levado, branco, puro.

Um exame desta oposição entre rio (homem) e mar nos leva a considerar, contrapostos, dois campos semânticos no poema: o do viscoso e 0 do cortante. Fazem parte do primeiro expressões como: "lodo e ferrugem", "lama", "mucosa", "polvos", "mulher febril que habita as ostras", "flores pobres e negras", "flora suja e mais mendiga", "cadela fecunda", "parto fluente e invertebrado", "fecundidade pobre", "grávido de terra negra", "sujo e abafado", "estagnação". Elas se prendem a rio. O homem será insistentemente caracterizado por perder-se na lama. Como é igual ao rio, os atributos daquele the servem de igual modo.

Em torno do cortante, alinhariamos: "inquietação de faca que há nos peixes" (à que não se abre o rio), explodir (o rio cresce sem explodir), ferver (rio: "iamais o vi ferver" - p. 306), roer (de que não é capaz aquele homem; ele é roído), sangrar, gritar (de que não é capaz aquele homem - sua vida é dissolvida, e não mastigada; a água macia amolece seus casos). $E$, quando surge o mar: "azul e branca", ter dentes, "sabão roendo suas praias", "roedor puro", "lavando seu puro esqueleto de areia" (reparar que 'esqueleto' implica em dureza, idéia que surgirá adiante), "ácidos"12.

Resumamos os traços mais relevantes:

11 Deixaremos de lado, neste estudo, a discussão do discurso poético do autor de o engenheiro - a lógica de sua composição, seu antilirismo, sua poética negativa/construtiva, próxima de uma prosa, "a palo seco", etc. Consultar, além los trabalhos já citados. LIMA, Luiz Costa. Lira e antilira. Rio de Janeiro, Civilização Brasileira, 1968. CAMPOS. Haroldo de. O geômetra engajado. In : - Metalinguagem. Petrópolis. Vozes, 1967. p. 67.78. NUNES, Benedito. A máquina do poema. In : —. 0 dorso do tigre. São Paulo, Perspectiva, 1969. p. 265-75́. MERQUIOR, José Guilherme. Nosso poeta exemplar. Jornal do Brasil. Livro. Rio de Janeiro, 9 fev. 1980. NUNES faln em "estilo de negatividade". João Cabral de Melo Neto, p. 141.

12 Claro está que nem todos estes rocábulos, em sua versão dicionarizada, seriam reIutíveis ro sema cortante, ou ao sema viscoso. No caso, o poema os conota, incluindo-os nesta ou naquela constelaçāo semântica. 


\section{viscoso}

- sujo, impuro

- terra negra, lama

- estagnação, parado

- dissolver, amolecer

- já rĩo pode falar

- não roer, não ferver

- SEM DENTES

\section{cortante}

- limpo, puro

- praia/areia branca, lavada

- (movimento)

- sangrar, gritar, explodir

- sempre diz a mesma coisa

- roer, (ferver)

- TEM DENTES

Cumpre registrar que em Cabral as imagens do cortante estão dotadas de um sinal extremamente positivo. O que é cortante reage, resiste, e uma pesquisa mais acurada poderia mostrar o quanto tais imagens são privilegiadas em sua obra. O rio leva sinal negativo na medida em que, por exemplo, ele jamais se abre "à inquietação de faca que há nos peixes" (p. 306). Da mesma forma, ele não explode, assim como o homem não rói, a vida dissolvida, os ossos amolecidos pela água macia e lamacenta do Capibaribe. Ambos não cortam. Daí ser importante destacar, conforme frisamos, que ao homem ribeirinho se associa a idéia de sem dente, ao passo que o mar tem dentes.

A fábula ilustra uma parábola da luta. Porque nesta parte é configurada uma zona fronteiriça, nem mar nem rio, que são os mangues. Neles o rio se prepara para enfrentar o mar:

Mas antes de ir ao mar

o rio se detém

em mangues de água parada.

Junta-se o rio

a outros rios

numa laguna, em pântanos

onde, fria, a vida ferve.

Junta-se o rio

a outros rios.

Juntos,

todos os rios

preparam sua luta

de água parada,

sua luta

de fruta parada. (pp. 314-15)

Na passagem, percebe-se - "água parada" - que os mangues 
estăo mais ligados a rio (logo, ao viscoso). Mas nos chama a atenção que, em seus pântanos, "fria, a vida ferve" (o 'ferver' é uma Falavra do campo semântico oposto - o do cortante). 0 mar, que queria "destruir no rio / suas flores de terra inchada, / tudo o que nessa terra / pode crescer e explodir" (p. 314), recebe uma resposta do rio através dos mangues pelos mangues, resultado de uma uniāo, os rios reagem. A luta encerra a liçāo: resistiu. O poema sofre, aqui, uma torça. A partir de agora o tetxo engendra uma a írmação. Nos mangues - comparados a uma fruta, "trabalhando ainda sem açúcar / depois de cortada" (p. 315) - se esboça a "força invencivel e anônima", que funciona como uma "máquina". Neste €spaço, que será o da "vida espessa", se forja a resistência, lição que o rio aprendeu na fábula, e que o homem do Capibaribe aprencerá na moral desta mesma fábula, que é a última parte, o discurso do Capibaribe.

Portanto, do choque entre rio $x$ mar, viscoso $\times$ cortante, emerge a moral da resistência ${ }^{13}$, configurada num terceiro campo, o do espesso - o que resiste é espesso. A última parte, com efeito, insıste na "espessura do que vive": o que vive é agudo, não entorpece, fere, incomoda; o que vive tem dentes, é espesso. Resiste, corta. Ao espesso correspondente a idéia de dureza, que se opõe ao mole do viscoso e que não encontrávamos bem delineada no cortante.

Completamos entāo o quadro:

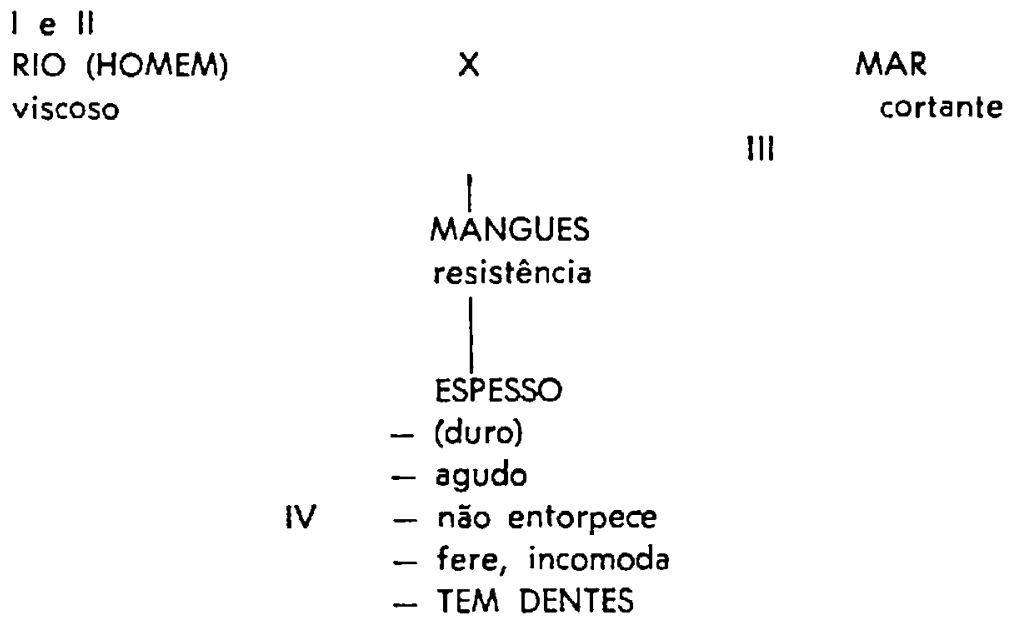

1. NUNES, Jolo Cabral de Melo Neto, n. 169-70. Ver nota 25. 
As duas primeiras partes, portanto, pintavam as paisagens geográfica e humana do Capibaribe, peculiarizadas pela lama, pelo viscoso; a terceira parte é uma fábula, parábola da luta do mar com o rio, o qual se prepara em mangues para resistir. Esta é a lição que a quarta parte reafirma -- a "moral da resistência", ensinamento ao homem do Capiabribe. O mar é marcado pelo cortante, e o que vive (discurso do Capibaribe), aprendida a lição, pelo espesso (isto $\hat{e}$, duro, resistente). No poema, pois, as duas primeiras partes se opōem à terceira, e esta, transição, dá surgimento à quarta parte:

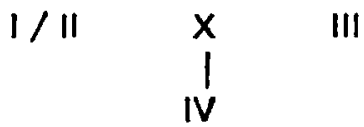

A "fábu espessa" a que se refere a antepenúltina estrofe é esta história do Capibaribe, com seus seres sem pluma, contada pelo poema. O poema, escrevemos, passa esta moral so homem do rio. Ao leitor, ele conscientiza. Em outros termos: o ensinamento que - leitor extrai do texto ${ }^{14}$ se relaciona com a progressiva desmistificação das imagens do senso comum a que nos reportávamos mais atrás. Ao terminar a leitura de "O cão sem plumas" o leitor aprende esta lição de "natureza desfalcada", do rio-lama, dos homens-lama, que o poema ensina. Desmascara-se a visão "oficial" do rio - "seus olhos/ vinham pintados de azul/ nos mapas" (p. 308) -, ataca-se a indiferença das " 'grandes famílias espirituais' da cidade" - que "chocam os ovos gordos/ de sua prosa", cuja preguiça é "viscosa" (notar que se alinham no campo semântico do viscoso) -, "de costas para o rio". E claro que tais famílias pernambucanas são as dos senhores de engenho (v. referência a açúcar), dotados de poder econômico e, conseqüentemente, político.

O poeta dizia, do rio, que jamais o vira ferver (p. 306), e que "o rio fluía / como uma espada de líquido espesso./ Como um cão/ humilde e espesso" (p. 308). Uma vez ensinada a resistência, percebemos que o rio, captado de uma forma mais real l'todo o real é espesso" - p. 317), encerra suá lição de realidade contunden. te: "o que vive é espesso/ como um cão, um homem,/ como aquele rio" (p. 316), lição que o poeta guarda na memória ("aquele rio/ está na. memória/ como um cão vivo/ dentro de uma sala" p. 316).

14 'Deste modo, a lição é menos 'extrafin das prónring ákuas do Cuplbaribe' do que do objeto construido (o poeniH) lur intermblio do qual foi possivel apreendè-las". BARBOSA, p. 108. 
Colocamos que o rio e o homem eram caracterizados pelo que thes era negado. De fato, o texto desce ao mais extremo de uma escala -

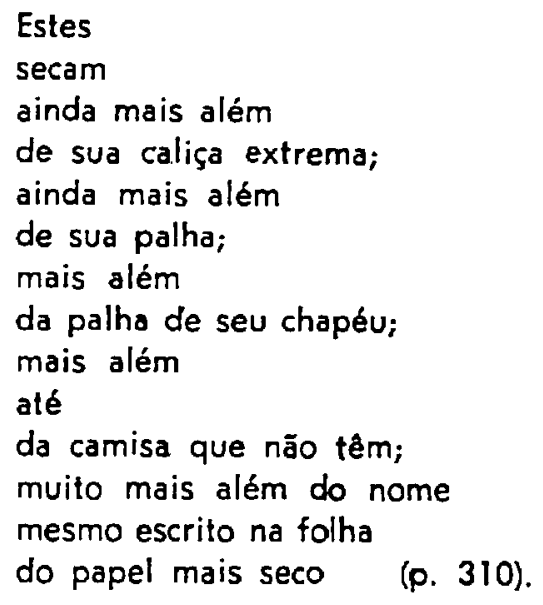

eté chegar ao "fio de homem", que se rompe (p. 311). Na mais total privação, nada mais tem este homem: como vimos, não sa sabe "onde começa o homem/ naquele homem" (p. 311).

Só então é que se efetua o percurso inverso. Após negar ao máximo, após roer tão fundo, "até o que nāo tem" (p. 309), é que - conquista da vida, o espesso se afirmam, ocupando o poema:

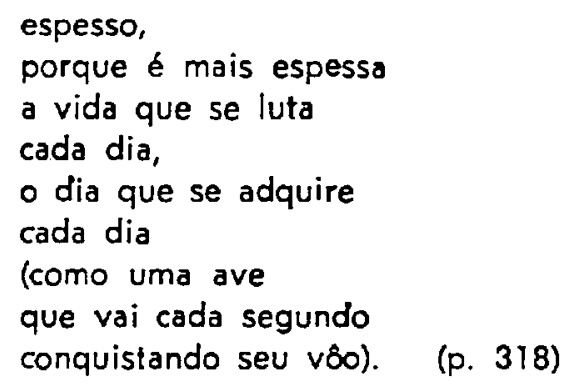

Paralelamente, o poema evidencia metalingüisticamente sua arquitetura metafórica: se rio e homem eram aproximadas a cão sem plumas, o mar o será a uma bandeira e o mangue a uma fru. ta 1.5 .

'O exame de "O cão sem plumas" nos proporciona o seguinte esquma":

15 Benedito NLNES discorre sobre este "molde deseritivo", dotado de um valor metapoético. Joino Cabral de Melo Neto, p. 65-6. 
O texto tem um sentido socia!: revela "as indigências e a perúria do meio regional do poeta" " 1 . O real, enfatizemos, é espesSo. O poema, ácido, que rói, fere, incomoda em sua contundência. Não podemos ficar indiferentes, como as famílias de Recife nele mencionadas. Ao invés, ficamos de frente para o rio.

\section{A CHAMA MORTIÇA}

"Morte e vida severina" transforma a tradição dos autos nata$\operatorname{linos}^{17}$ ( $v$., por exemplo, Gil Vicente), na medida em que aqui temos um contexto de referência pernambucano, um aproveitamento de eiementos da literatura popular (a redondilha maior é comum no romanceiro nordestino) e, em vez de preponderar o enfoque religioso, a dominante é novamente a crítica a uma cendição miserável e severina.

O texto desenvolve a metáfora-título ${ }^{18}$ e narra o percurso do retirante, acompanhando o curso do rio, desde a caatinga, passando pelo agreste e pela zona da mata, até o Recife. Está constituído em dezoito cenas ${ }^{19}$. As de número ímpar apresentam o personagem Severino sozinho. Nas de número par, ele ou contracena com outros personagens ou assiste a seus diálogos. Esta estrutura de alternância é interrompida na cena de número 13, quando o poema sofre a sua torsäo e tem inicio o "auto dentro do Auto"20.

Logo no início o protagonista se apresenta ao leitor (ao público): é a Severino que emigra. Há muitos Severinos. Sua problemática é coletiva, não concerne a um único indivíduo. Ele é, por isso,

16 NUNES,p.64

17 "Podemos, nté mesmo, estabelecer, quase que de cena a cena. os traços analóxjems desse parenteseo formal, que as mưdanças de fikuras e situaçốes hpenas conseguem lisfarcar: uma mulher do povo substitui o snjo da Anuneiaçáo os vixinhos, com o* seus eloxios, tomam o lugar dos anjos que guardam e udoram o menino, e, com os scup presentes. o dos rois magos: o mucnmbo é o presépio do Menino-Deus, e seu Jose, sĩn José." NUNES, Joāo Cabral de Melo Neta, p. 86. Ele advertirá, todavia, que, enquanto o pastoril sncraliza a ordem gocial existente, c. "morte e vida severina" esta funçano ideológien á neutraliz:adn, pois ele tem motivngōez diversas. Ver p. 87.

18 Cf. LIMA, Luiz Costa. Lirs..., p. 323.

19 Benedito NCNES nos evidencin a ambivaléncia do textn: "narrativo, quanto so encadenmento e ao episôdio das cenas que o compōe, e drnmático qunnto no enráter zeral ha nçūo que pe desenrola através dessas cenas. Cube ao personegem a iniciativa de começur o relato de sua histórin, cujo desenvolvimento. apresentado em quadron aucessivos, precedidos de entrechos narrativos que descrevem antrcipadnmente um acontecimento, ou umn situnçüo, produzcm-se sob diversas formns: monólogos, díálogos, Inmentos e elogion". Joăo Cahrnl de Melo Neto, p. Bir.

20 NUNES, Joũo Cabral de Melo Neto, n. 85. 
uma "figura exemplar"1.

Com efeito, os Severinos são "iguais em tudo na vida", iguais na morte, "iguais em tudo e na sina" - "a de querer arrancar/ alGum roçado da cinza" (p. 204). Define-se a morte severina:

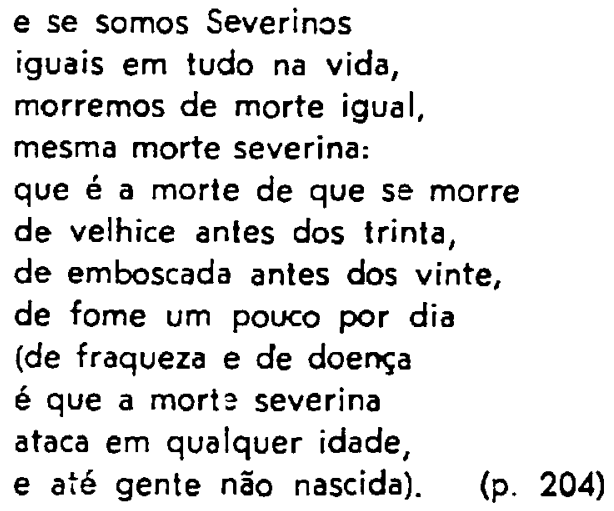

A morte será afirmada ( $\mathrm{m}$ conseqüência, a vida negada) até nuscer o menino. Praticamente todas as cenas contêm a presença oa morte ${ }^{22}: 1,2,4,5,6,8,10,11$ e 12.

Na cena 2, por exempio, dois homens carregam um defunto também chamedo Severino, lavrador, que morreu numa emboscada. Tinha uns cobiçados hectares de terra. O texto é metafórico: a "ave-bala" da espingarda queria mais espalhar-se", necessitando para "voar mais livre" das dez quadras do lavrador (p. 207).

Importa salientar também o cultivo deste agricultor: "pedra e oreia lavada"; ele "plantava palha" (p. 206). Estas alusões se inscrevem nas "coisas de não", que ressurgem na cena 4, quando se canta as excelências: um homem, do lado de fora, diz a rubrica, vai parcodiando as palavras dos cantadores, o que as desconstrói criticemente, revelando as condiçōes de vida do nordeste ${ }^{23}$. Vamos reencontrando a negatividade que depreendíamos em "O cāo sem plumas", a caracterização pəlo que falta. E a "vida que é menos" com que se depara Severino retirante:

2: "Assim, o rersonazem de "Morte e vika severina" 6 ama likura exemplar, como smem ser, nos Autos, an fersonse dramatis. que representam tipos e encarnam prinépios, num plano alezórico, de significado relizioso-ético". NUNES, Jol̆o Cabral de Mielo Neto, p. 83.

22 Assinala Juāo Alcxandre LARBOSA a preseņ̧a da morte como constante narrativa, num texto que objetiva o nascimento. p. 124. 


\section{- Desde que estou retirando}

só a morte vejo ativa,

só a morte deparei

e às vezes até festiva:

só morte tem encontrado

quem pensava encontrar vida,

e o pouco que não foi morte

foi de vida severina

(aquela vida que é menos

vivida que defendida,

e é ainda mais severina

para o homem que retira). (p. 211)

E ainda a morte que marca o quadro 6. O único trabalho existente é o que com ela lida: "como aqui a morte é tanta// vivo de a morte ajudar" (p. 215). Ali - no agreste - "só os roçados da morte/ compensam (...) cultivar" (p. 216). Compare-se com o que diz o retirante a respeito de onde ele vem (ele, que arrancava "algum roçado da cinza", no quadrol): sempre foi "lavrador de terro má", se sentia capaz de arar até "a calva da pedra", tratava do "gado de comer do chão/ ou de comer ramas no ar" (pp. 213 e 214). Ainda a negatividade.

Aos poucos, vamos constatando que não há diferença entre a caatinga, o agreste e a zona da mata. A miséria, severina, é a mesma. Quando chega a esta última, tem esperança: rios ali "têm a água vitalícia", a terra, em contraste com a "piçarra da Caatinga", com a qual ele estava acostumado, the parece "fácil de amansar", "feminina" (p. 217). Daí ele declarar: "decerto a gente daqui/ jamais envelhsce aos trinta/ nem sabe da morte em vida,/ vida em morte, severina" ( $p .218$ ).

No entanto, analogamente à sua chegada ao agreste (cena 2), ele assiste a um enterro, desta feita de um trabalhador de oito. Se c outro lavrador tinha dez quadras, a. este cabe a cova, como sua parte da terra que queria "ver dividida": "é uma cova grande/ pa-

23 Sobre a passagem comenta Luis Costn LIMA: "k parólia dos homens às rezadeiras - paródia à nalavras que fundem egpernnga esquecendo o que nāo deverinm enqurcer. A excelêncin ensina ao defunto o truque te como enxanar os demónios. Mas nor $t a l$ ensino. as rexadeirag engnnam o morto a a si mesmas, pos 'esquecem' que $n$ morto nāo tem messio por que enganar a quem seja. Fois nāo é cordão. cera - vela o que ele leva, dois leva apenns uma soma de nāo. A paródia dos bomens exerce-se portanto em duis nívejs: 6 uma paródia à lirica, dentro da linguagen". Lira.... D. 322. Renedito NUNES também alude ì cena, com ela ilustrando a neutralizaçáo ideolóxica da forma literária usadn 10 Auto). Joso Cabral de Melo Neto, D. 87 . 
ra tua carne pouca,/ mas a terra dada/ não se abre a boca" (p. 219).

Ou seja: impera a mesma ordem social. Igualam-se agreste e zona da mata. De fato, o retirante o percebe: "mas não senti diferença/ entre o Agreste e a Caatinga,/ e entre a Caatinga e aqui a Mata/ a diferença é a mas mínima" (p. 222) - em todos os lugares "a vida arde sempre com/ a mesma chama mortiça" (p. 223).

Resta o último estágio da viagem: Recife. Entretanto, lá chegando ouve a conversa de dois coveiros - presença da morte. A uma certa altura, falam da gente retirante, "que vem do Sertão ce longe". As perspectivas para os que emigram - não têm onde trabalhar, nem onde morar, $n \equiv m$ onde se enterrar; viverão, como os homens do Capibaribe em "O cão sem plumas", no meio da lama, comendo os siris que apanham - levam os coveiros a sugerir "que os sacudissem de qualquer ponte/ dentro do rio e da morte". Para os dois trabalhadores com a morte (único trabalho disponível em todos os lugares por onde passou Severino), "morre gente que nem vivia" (p. 228).

Temos então que se identificam todos os espaços percorridos por Severino, marcados pela negatividade, pela morte:

CAATINGA $=$ AGRESTE $=$ ZONA DA MATA $=$ RECIFE

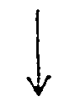

morte

(mesma paisagem humana e social

Fica decretado o fim das esperanças de Severino (v. cena 11) ${ }^{24}$ : ele vinha seguindo o seu próprio enterro (p. 229). O protagonista acata a sugestão dos coveiros. $E$, prestes a "apressar a morte", encontra seu José, mestre carpina (atentar para o nome e a profissão, que evocam o pai de Cristo), que será aqui o porta-voz da moral da resistência"s: "sei que a miséria é mar largo,/ não é

24 Para Joāo Alexandre BARBOSA, este é o momento crucial do Auto: "aquele em que esperança que moveu as pernas do retirante começa a desvinecer-ze por força e crueza de uma sitauçāo social muito pior do que a esperada." p. 125.

Extraímos a expressão das conclusōes do ensaio de Benedito NUNES. Para ele, a visão ética da poesia de Cabral baseia-se num "mechusamento de subjetividade". Nesta visão, "o mundo e o homem, a suciedade e 0 indivíduo, em posiçäo de partes adversas, confrontam-se hostilmente e tratam-se com dureza. A agressäo do mundo e da sociedade, opūe o individuo a agressão contrária e obstinada de sua resistencia pétrea. Vontade negati:a, a vontade de petrificar hostiliza o mundo que a hostiliza". Joāo Cabral de Melo Neto, p. 169-70. 
como qualquer poço:/ mas sei que para cruzá-la/ vale bem qualquer csforço"; "o mar de nossa conversa/ precisa ser combatido" (p. 231); "a vida de cada dia/ cada dia hei de comprá-la" (versos muito semelhantes aos que encerram "O cão sem plumas") (p. 232); "mas o que compro a retalho/ é, de qualquer forma, vida" (p. 233).

Está o retirante na iminência de saltar "fora da ponte e da vida" quando uma mulher, no quadro13, anuncia a Seu José que seu "filho é chegado" - "saltou para dentro da vida" (grifamos - $p$. 233). E a anunciação.

Dá-se neste momento a torção do poema: tal e qual "O cão sem plumas", depois de caracterizar pela negatividade e pela carência (morte $\mathrm{Em}$ vida/ em morte), igualar todos os espaços (em "O cão sem plumas" coincidiam rio, lama, terra, hömem; aqui equivalem a Caaringa, o Agreste, a Mata, o litoral), afirmar a morte, chegando Severino ao extremo do suicídio (o "máximo menos"), o texto inverte seu caminho: o auto natalino afirma a vida, ainda que vida severina ${ }^{2 h}$.

Os presentes trazidos (comparar com os reis magos) se inserem na pobreza que peculiariza o espaço dos severinos: caranguejos, papel de jornal, boneco de barro. Ali também todos são iguais: irmãos "de leite, da lama, de $a^{\prime \prime}$ (p. 35). As ciganas profetizam a vida do recém-nascido: será anfíbio "como a gente daqui mesmo" (como - homem ribeirinho do Capibaribe), viverá na lama e catará pelo chão "tudo o que cheira a comida" (p. 237). A outra the augura um futuro de operário, o que permitirá mudar-se destes mangues "daqui do Capibaribe/ para um mucambo melhor/ nos mangues do Beberibe" (p. 238). O trecho não podia ser mais irônico. A mesma riséria se faz presente nas profecias das duas ciganas.

O quadro 17 afirma o humano, assim coms a última parte de "O cão sem plumas" ratificava o espesso - apesar de ser magra, pálida, franzina, pequena, esta criança tem "peso de homem", "marco de homem", "marca de humana oficina" (p. 239) -, bem como a. formosura e beleza, o novo que representa o recém-nascido, além de Enfatizar a resistência: "- Belo porque corrompe/ com sangue novo a anemia/ - Infecciona a miséria/ com vida nova e sadia" (p. 240).

Na cena derradeira, Severino, que estivera de fora, sem tomar

26 Acentua Joäo Alexandre BARBOSA o caráter de celebraçāo negativa do auto den-

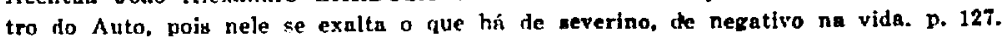


parte em nada, fonforme nos informa a rubrica, reaparece para escutar de Seu José a resposta à pergunta "se não vale mais saltar/ fora da ponte e da vida". Apesar de ser difícil defender "só com palavras a vida", ela mesma respondeu, "com sua presença viva". Agora delineia-se na outra extremidade do poema, a vida severina:

mesmo quando é assim pequena

a explosão, como a ocorrida;

mesmo quando é uma explosão

como a de há pouco, franzina;

mesmo quando é a explosão

de uma vida severina.

O percurso do poema, por conseguinte, vai da AFIRMAÇAO DA MORTE (negação da vida) à AFIRMAÇAO DA VIDA - do homem (negação da morte). A troca se processa, como vimos, na cena 13. Isto no tocante à arquitetura do texto. Quanto à sua semântica, a vida, severina, é, outra vez, uma resposta/resistência à morte se-

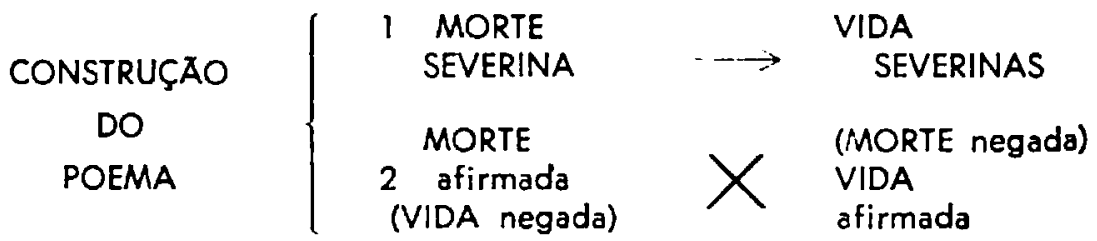

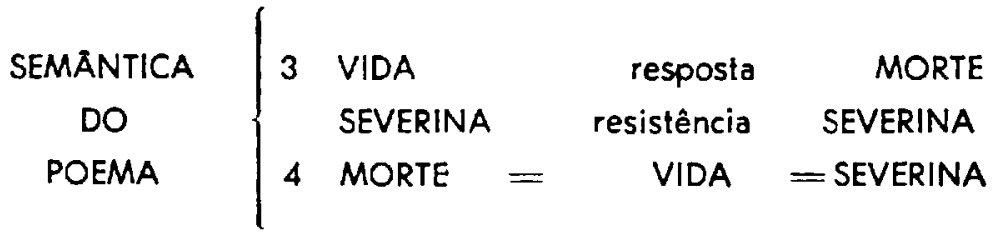


verina. Porém, em certo sentido, ambas se igualam, pois são severinas $^{2 \pi}$.

Benedito Nunes caracteriza a severinidade, identificando-a ao desplumado do poema anterior. Vale a pena transcrever a passagem: são severinos todos os retirantes que a seca escorraça do sertão e que o latifúndio escorraça da terra. A palavra perde então o seu caráter substantivo, e o ser que ela designa a sua substância: "severino" adjetivo qualifica a existência negada. Essa mudança de categoria gramatical, que corresponde a uma mudança de categoria na existência social, é a mesma com que já deparamos em "o cão sem plumas", sob a forma do não ser permanente do homem. Pode-se, conseqüentemente, volfar ao nome em sua substantividade, mas já como gênero abstrato - a severinidade de una situação humana de carência, que designa igualmente todo aquele que dela participa ${ }^{28}$.

O auto encerra, novamente retomando "O cão sem plumas", uma lição didática: que a severinidade pode ser ultrapassada. Recorremos uma vez mais a Benedito Nunes:

à filosofia do desespero e do suicidio vivida pelo retirante, seu José responde com a necessidade de afirmaçāo da vida, figura didática extraída da alegoria naialina, e que implica numa negação do estado de existência para 0 indivíduo. Aprende-se, com tal desfecho, que a condição severina não é permanente, que a severinidade constitui uma entificação determinada de fora para dentro. (...) A implosão da vida severina poderá tornar-se uma explosão?

\section{OS DENTES DO POEMA}

As análises de "O cão sem plumas" e de "Morte e vida severina", poemas do "tríptico do Capibaribe", nos revelaram que ambos os textos contêm uma crítica.social, problematizando as paisasens física e humana das regiōes atravessadas pelo rio Capibaribe.

Ambos, por outra parte, como que se estruturam na base do mesmo mecanismo: negação/ afirmação. Tal arquitetura, contudo,

27 Os dois termos do percurso de Severino, morte e vida, estāo igualados por idíntica metrutura social, escreve o mesmo critico. BARnOSA, p. 125.

28 NUNES, Joȟo Cabarl de Melo Neto, p. 82.

29 NUNES. Joño Cabral de Melo Neto, p. 89. 
extrapola o âmbito da construção do poema, para se insertar numa órbita ética, moral e social: a negação diz respeito à penúria, d̀ carência, à natureza desfalcada, à privação do homem nordestino. Podemos escrever: ser "cão sem plumas" é ser "severino". Trata-se da mesma condição "desplumada", "severina".

Os dois textos não escondem seu caráter didático. E sua lição maior é a resistência. Esta a moral que encerram. Ao leitor, eles ensinam a realidade espessa do Capibaribe.

Verificamos assim - retomando reflexão esboçada no princípio deste trabalho - que 0 exilio de João Cabral se transforma, num exilio na linguagem. $E$ na linguagem, no poema, no verso, que ele recupera, poeticamente, o homem e o cenário pernambucanos.

A "espessura" que confere a este homem e a esta paisagem, em seus poemas, os fazem cortantes, contundentes, incômodos. A linguagem poética cabralina tem dentes. Vira faca, afiada, fere ${ }^{30}$. Os dentes do poema mordem o real e o desnudam para o leitor, "como se bate numa porta a socos" ${ }^{\prime 31}$.

30 Como já dissomos, seria interessante rastrear as imagens do cortante na produça do poeta de A edueação pela pedra. No fragmento $H$ de "Uma faca só lâmina", por exemplo, o trabalho com as palavras é aproximado a faca. Benedito NUNES acena para idêntica via, dos dentes da lingagem, ao terminar seu ensaio mostrando como - multíssimbolo pedra - que sintetiza em si o ideal poético de contenção e o idcal éticoj de resistència - se transforma em "làmina de faca". p. 171.

31 Alusāo so poema "Graciliano Ramos" (p. 75-6), o qual poderia ser tomado como excelente "estudo" a propósito da literatura do eseritor de Vidas Secas, bem como súmula da poesia cabralina (fase dos textos aqui abordados), pois nele se discorre sobre a linguagem (duas primeiras estrofes), a temática (3." e 4." estrofes), o nordestino "por quem fala" (5." e 6." estrofes) e o destinatário (duis ultimas estrofes). Em suma: secura do verbo, secura da paisagem, secura do homem - tudo partilbando da mesma natureza desplamada e sererina - e a ligão didática que conseientiza, incomoda o leitor. José Guilherme MERQUIOR, em artigo que celebrava os sessenta anos do poeta pernambucano. nos fala de uma "roesia de pés na terra, regida pela referencialidade à contingência humana". E mencionava a fidelidade de João Cabral de Melo Neto ao nobre compromisso que, sem diminuir em nada a qualidade da primeira, enriquece de muito a nossa intelizéncia da sezunda. p. 10 . 


\section{R E S U M O}

Este trabalho analisa dois poemas de João Cabral de Melo Neto - "O cão sem plumas" e "Morte e vida severina" -, pertencentes ao chamado tríplico do Capibaribe, procurando mostrar a, similaridade de sua arquitetura - negação/ afirmação -, além de explorar Sua semântica. Em Cabral, a. negatividade extrapola o plano da construção para sa matizar de um valor ético, moral e social - o poema tem dentes. Ambos os poemas, por outro lado, encerram um caráter didático, ensaiando a moral da resistência. O estudo sugere aında que o poeta recupera o Nordeste em seus poemas, transformando desse modo seu "exílio" num exílio na linguagem.

This paper analyses two poems by João Cabral de Melo Neto - "O cão sem plumas" and "Morte e vida severina" -, which be. long to the so called Capibaribe triptic, trying to reveal the similarity of its architecture - negation/afirmation -, besides of exploring its semantics. In Cabral, the negativity go beyond the construction level to acquire an ethic, moral and social value - the poem has teeth. Both poems, on the other hand, have a didatic character, teaching the moral of resistence. The study sugests also that the poet recuperates the Northeast region in his poems, in such a way that his "exile" becomes an exile in the language.

\section{REFERENCIAS BIBLIOGRAFICAS}

1 BARBOSA, J.A. A imitação da forma; uma leitura de Joăo Cabral de Melo Neto. São Paulo, Duas Cidades, 1975. 229 p.

2 CAMPOS, H. Metalinguagem. Petrópolis, Vozes, 1967. 111 p.

3 CULLER, J. Structuralist poetics. Ithaca, Cornell University Press, 1975. 301 p.

4 ISER, W. The act of reading. Baltimore, Johns Hopkins University Press, 1978.

5 LEITE, S.U. Participação da palavra poética. Petrópolis, Vozes, 1966. 108 D.

LIMA, L.C. Lira e antilira. Rio de Janeiro, Civilização Brasileira, 1968.

7 _ , org. A literatura e leitor. Rio de Janeiro, Paz e Terra, 1979.

8 Melo NETo, J.C. Poesias completas. Rio de Janeiro, Sabiá, 1968.

9 MERQUIOR, J.G. Nosso poeta exemplar. Jornal do Brasil. Livro, Rio de Janeiro, 9 fev. 1980.

10 NUNes, B. O dorso do tigre. São Paulo, Perspectiva, 1969. 278 p.

11 _...... Joño Cabral de Melo Neto. 2. ed. Petrópolis, Vozes, 1974. 217 p.

12 Reis, R. A leitura como d’íalogo. Correio do Povo. Caderno de Sábado, Porto Alegre, p. 16, 19 ago. 1978.

13 Ler/dialogar; notas para uma teoria da literatura. Minas Gerais. Suplemento Literário, Belo Horizante, 13(634): 4-5, 18 nov. 1978.

14 - O lugar da crítica e a crítca do lugar. Minas Gerais. Suplemento Lite rário, Belo Horizante, 14(681): 6-7, 20 out. 1979.

16 Por uma teoria da leitura. Revista de Caltura Vozes, 71(10): 135-40, 197 ?

It: RIEDEL, D.C. et alii. Literatura brasileira em curso. 4. ed. Rio de Janeiro, Bloch, 1971. $477 \mathrm{p}$. 